\title{
Massa Kalsium dan Massa Protein Daging Akibat Penggunaan Tepung Limbah Wortel (Daucus carota L) dalam Ransum Ayam Broiler
}

\section{Calcium and Protein Meat Mass due to the Use of Waste Product of Carrot Powder in Ration}

\author{
Prabowo, L. D. Mahfudz, dan U. Atmomarsono \\ Program Studi Peternakan Fakultas Peternakan dan Pertanian Universitas Diponegoro Semarang \\ Jl.drh. R. Soejono Koesoemowardojo, Tembalang, Kota Semarang, Kode Pos 50275 \\ Corresponding e-mail: pbowobowo@gmail.com
}

\begin{abstract}
The Study was aimed to determine the effect of waste product of carrot (Daucus carota. L) powder in broiler chickens ration on protein and calcium meat mass. The benefit of this research can provide information on the utilization of waste product of carrot as a broiler chickens feed. The materials used were 144 broiler chickens ( 7 days old) with initial body weight $181.40 \pm 11.31 \mathrm{~g}$. This research used completely randomized design (CRD) with 4 treatments and 6 replications, each experimental unit contained six chikens. The treatment was waste product of carrot powder at levels T0 (0\%), T1 $(2 \%), \mathrm{T} 2(4 \%)$, and T3 $(6 \%)$. Parameters measured were, protein and calcium meat mass. Data were statically analyzed by analysis of variance and continued to Duncan test when the treatment effect was significant. The result showed that giving of waste product of carrot into the ration could decrease of protein meat mass, while calcium meat mass did not show significant effect. The conclusion feeding waste product of carrot powder into the diet was not more than $2 \%$.
\end{abstract}

Key words: broiler chikens; waste product of carrot; $\beta$ - caroten; protein and; calcium meat mass.

\begin{abstract}
ABSTRAK
Penelitian ini bertujuan untuk mengkaji efek pemberian tepung limbah wortel (Daucus carota L) terhadap massa protein dan kalsium daging ayam broiler. Manfaat dari penelitian ini dapat memberikan informasi tentang pemanfaatan tepung limbah wortel sebagai pakan ayam broiler. Materi yang digunakan adalah 144 ayam broiler (umur 7 hari) dengan rata- rata bobot badan awal 181,40 $\pm 11,31 \mathrm{~g}$. Penelitian ini menggunakan rancangan acak lengkap (RAL) dengan 4 perlakuan dan 6 ulangan, masing - masing unit percobaan terdiri dari 6 ekor ayam. Perlakuan yaitu pemberian tepung limbah wortel pada tingkat T0 (0\%), T1 (2\%), T2 (4\%), dan T3 (6\%). Parameter yang diukur adalah, massa protein dan kalsium daging. Data dianalisis secara statistik dengan analisis varians dan dilanjutkan uji Duncan bila terdapat perlakuan yang signifikan. Hasil penelitian menunjukkan bahwa pemberian tepung limbah wortel ke dalam ransum dapat menurunkan massa daging protein, sedangkan massa kalsium daging tidak berpengaruh signifikan, kesimpulan adalah pemberian tepung limbah wortel dalam ransum tidak boleh lebih dari $2 \%$.
\end{abstract}

Kata kunci: ayam broiler; tepung limbah wortel; $\beta$ - caroten; massa protein dan massa kalsium daging

\section{PENDAHULUAN}

Ayam broiler merupakan ayam pedaging yang memiliki pertumbuhan yang cepat, ukuran tubuh yang besar, temperamen yang tenang serta lebih efisien dalam penggunaan ransum, namun ayam broiler sangat rentan akan penyakit dan stress. Produksi daging ayam yang berkualitas tinggi, pakan yang diberikan juga harus memiliki kualitas yang baik. Pakan yang berkualitas baik pada umumnya memiliki harga yang mahal, oleh karena itu para peternak harus dapat memanfaatkan bahan pakan yang ada disekitar nya atau bahan pakan inkonvensional (bahan yang tidak umum digunakan) salah satu nya limbah wortel.

Limbah wortel merupakan sisa dari hasil budidaya wortel yang tidak layak untuk dikonsumsi. Limbah wortel berasal dari wortel yang tidak dijual dikarenakan tidak lolos sortir dan tidak dimanfaatkan dari hasil panen. Limbah wortel tersebut sebetulnya dapat dimanfaatkan sebagai bahan pakan ternak antara lain ayam broiler. Wortel 
memiliki protein kasar $7,0 \%$, serat kasar $5,1 \%$ dan memiliki kandungan $\beta$ - caroten sebagai provitamin A yang tinggi yaitu sebesar 12.000 S.I. atau $7125 \mu \mathrm{g}$ (Tanuwiria et al., 2008). Wortel juga mengandung vitamin B kompleks terdiri dari thiamin (B1) sebesar 0,06 mg, riboflavin (B2) sebesar 0,04 $\mathrm{mg}$, piridoksin (B6) sebesar 0,138 mg, vitamin C sekitar 6,00 $\mathrm{mg}$, vitamin $\mathrm{E}$ (tocopherol) sebesar 0,66 mg (Diva, 2014). Wortel mengandung beberapa mineral penting berupa kalsium 33-55 mg, fosfor 35$43 \mathrm{mg}$ dan besi 0,3-1,67 mg (Olalube et al., 2015).Vitamin A, C, dan E dalam wortel dapat berperan sebagai antioksidan dan dapat mengurangi stress pada ayam. Selain itu $\beta$ karoten atau pro vitamin A dalam wortel diubah menjadi vitamin A yang berperan dalam diferensiasi sel epitel dan memelihara organ pencernaan sehingga akan mempengaruhi kecernaan dan penggunaan pakan. Meningkatnya efisiensi pakan dan kecernaan pakan pada ayam broiler dapat mempengaruhi sintesis protein dan asupan kalsium yang dapat mempengaruhi tinggi rendahnya massa protein dan massa kalsium dalam daging.

Massa protein daging merupakan suatu indikator untuk melihat baik atau buruknya deposisi protein yang dipengaruhi oleh sintesis dan degradasi protein (Minawarti et al., 2013). Massa protein daging dapat meningkat apabila protein yang disintesis melebihi protein yang degradasi yang akan mempengaruhi produktifitas ayam (Suthama, 1990). Massa protein pada daging ayam berhubungan dengan massa kalsium daging karena jumlah nilai massa protein daging dipengaruhi oleh kadar kalsium yang berbentuk ion (Winedar et al., 2006).

Massa kalsium dalam daging berperan sebagai aktivator aktivitas enzim proteolitik daging yang disebut calcium activated neutral protease (CANP), suatu enzim yang dapat memicu degradasi protein daging. Meningkatnya konsentrasi penyerapan kalsium menyebabkan peningkatan aktivitas CANP untuk degradasi protein sehingga akan menurunkan sintesis protein yang berakibat penurunan massa protein daging (Suthama, 1991). Tujuan dari penelitian ini adalah untuk mengkaji pengaruh tepung wortel terhadap massa kalsium dan protein daging ayam broiler

\section{MATERI DAN METODE}

Materi yang digunakan untuk penelitian yaitu ayam broiler strain Lohman unsex umur 7 hari sebanyak 144 ekor dengan bobot badan rata-rata $181,40 \pm 11,31 \mathrm{~g}(\mathrm{CV}=$ $0,21 \%$ ). Ransum yang digunakan terdiri dari jagung kuning, bekatul, meat bone meal (MBM), poultry meat meal (PMM), bungkil kedelai, tepung ikan, premix dan tepung limbah wortel. Limbah wortel yang berasal dari umbi wortel yang tidak layak dijual karena cacat yang oleh para petani hanya ditinggal di ladang. Kandungan bahan pakan ransum dapat dilihat pada Tabel 1 . Komposisi dan kandungan nutrisi ransum perlakuan periode starter dan finisher disajikan pada Tabel 2 dan 3.

Rancangan Percobaan yang digunakan adalah rancangan acak lengkap (RAL) dengan 4 perlakuan dan 6 ulangan, setiap unit percobaan diisi 6 ekor ayam broiler. Perlakuan yang diberikan selama penelitian adalah : T0 : Ransum tanpa tepung wortel, T1 : Ransum dengan tepung wortel $2 \%, \mathrm{~T} 2$ : Ransum dengan tepung wortel $4 \%$, T3 : Ransum dengan tepung wortel $6 \%$.

Data yang diperoleh dianalisis dengan menggunakan analisis of varian (ANOVA), dengan uji $\mathrm{F}$ untuk mengetahui pengaruh perlakuan penggunaan tepung wortel terhadap massa kalsium dan protein daging ayam broiler. Apabila terdapat pengaruh dilanjutkan dengan Uji Wilayah Ganda Duncan untuk mengetahui perbedaanan antar perlakuan (Steel dan Torrie, 1993).

Tahap penelitian dilakukan dengan beberapa tahapan yaitu tahap persiapan dan pelaksaan penelitian. Tahap persiapan penelitian meliputi tahap persiapan kandang, persiapan peralatan, pembuatan tepung wortel, dan pembuatan ransum. 
Tabel 1. Kandungan nutrisi bahan pakan

\begin{tabular}{|c|c|c|c|c|c|c|}
\hline \multirow[t]{2}{*}{ BahanPakan } & EM & PK & SK & LK & $\mathrm{Ca}$ & $\mathrm{P}$ \\
\hline & \multicolumn{6}{|l|}{$(\mathrm{kkal} / \mathrm{kg})$} \\
\hline Jagung Kuning* & $3.280,81$ & 7,55 & 8,33 & 2,26 & 0,03 & 0,0006 \\
\hline Bekatul* & $2.546,95$ & 11,61 & 26,70 & 7,50 & 0,0005 & 1,69 \\
\hline Tepung Ikan* & $3.131,05$ & 54,02 & 0,50 & 7,76 & 3,44 & 2,50 \\
\hline Poultry meat meal (PMM)* & $3.232,56$ & 57,90 & 9,72 & 12,13 & 1,01 & 2,24 \\
\hline Bungkil Kedelai* & $2.995,43$ & 47,53 & 7,60 & 0,51 & 0,05 & 0,69 \\
\hline meat bone meal (MBM)* & $2.673,66$ & 47,84 & 3,62 & 7,11 & 2,37 & 1,89 \\
\hline Tepung Wortel* & $2.487,12$ & 9,27 & 19,64 & 1,20 & 0,07 & 0,51 \\
\hline Premix* & 0,00 & 0,00 & 0,00 & 0,00 & 2,79 & 0,51 \\
\hline
\end{tabular}

Sumber :*Hasil Analisa Laboratorium Ilmu Nutrisi Ternak, Universitas Diponegoro, Semarang 2016

Hasil perhitungan EM didasarkan rumus balton yang dikutip oleh Anggrodi (1994)

$\mathrm{EM}=40,81\{0,87(\mathrm{PK}+2,25 \mathrm{LK}+\mathrm{BETN})+2,5\}$

Tahap persiapan kandang dilakukan dengan menyiapkan kandang dan membersihkannya dengan melakukan pengapuran dan desinfektan. Tahap menyiapkan peralatan yaitu dengan menyiapkan peralatan yang digunakan yang kemudian dibersihkan dan di-desinfektan.

Tahap pembuatan tepung wortel meliputi pengumpulan limbah wortel yang berasal dari daerah Kopeng, pencucian wortel, pemotongan wortel menjadi kecilkecil, pengeringan wortel dengan cara dijemur di bawah sinar matahari selama 3 hari, dan penepungan wortel dengan menggunakan grinder. Pembuatan pakan dalam bentuk ransum yang terdiri dari jagung kuning, bungkil kedelai, bekatul, tepung ikan, meat bone meal (MBM), poultry meat meal (PMM), premix, tepung wortel.

Tahap pelaksanaan penelitian meliputi tahap pemeliharaan dengan cara melakukan adaptasi pakan selama 1 minggu kemudian menimbang bobot awal ayam untuk mengetahui bobot ayam yang kemudian dimasukkan ke dalam kandang. Pemberian pakan dengan ransum perlakuan dilakukan 2 kali setiap hari pada pukul 06.00 dan 16.00 selama 4 minggu. Pemberian air minum dilakukan adlibitum. Tahap pengambilan data yang dilakukan mengenai massa kalsium daging, massa protein daging.

Tabel 2. Komposisi dan kandungan nutrisi ransum perlakuan fase starter.

\begin{tabular}{|c|c|c|c|c|}
\hline Bahan Pakan & T0 & T1 & $\mathrm{T} 2$ & T3 \\
\hline & & & & \\
\hline Jagung Kuning & 44,00 & 43,00 & 43,00 & 42,00 \\
\hline Bekatul & 20,00 & 19,00 & 17,00 & 16,00 \\
\hline Tepung Ikan & 4,00 & 4,00 & 4,00 & 4,00 \\
\hline Poultry meat meal (PMM) & 5,00 & 5,00 & 5,00 & 5,00 \\
\hline Bungkil Kedelai & 20,00 & 20,00 & 20,00 & 20,00 \\
\hline meat bone meal (MBM) & 6,00 & 6,00 & 6,00 & 6,00 \\
\hline Tepung wortel & 0,00 & 2,00 & 4,00 & 6,00 \\
\hline Premix & 1,00 & 1,00 & 1,00 & 1,00 \\
\hline Jumlah & 100,00 & 100,00 & $100,00$. & 100,00 \\
\hline \multicolumn{5}{|l|}{ Kandungan Nutrisi : } \\
\hline Protein Kasar (\%) & 23,09 & 23,08 & 23,03 & 23,03 \\
\hline Energi Metabolis (kkal/kg) & $2.999,32$ & $2.990,79$ & $2.989,59$ & $2.981,06$ \\
\hline Serat Kasar $(\%)$ & 11,25 & 11,29 & 11,15 & 11,19 \\
\hline Lemak Kasar (\%) & 3,94 & 3,87 & 3,74 & 3,67 \\
\hline $\mathrm{Ca}(\%)$ & 1,49 & 1,50 & 1,50 & 1,51 \\
\hline $\mathrm{P}(\%)$ & 0,80 & 0,80 & 0,77 & 0,76 \\
\hline Beta Karoten (\%) & 0,01 & 0,17 & 0,33 & 0,50 \\
\hline Vitamin A (\%) & 0,12 & 0,22 & 0,32 & 0,41 \\
\hline Vitamin E (\%) & 0,08 & 0,10 & 0,11 & 0,12 \\
\hline
\end{tabular}


Tabel 3. Komposisi dan kandungan nutrisi ransum perlakuan fase finisher.

\begin{tabular}{|c|c|c|c|c|}
\hline Bahan Pakan & T0 & $\mathrm{T} 1$ & $\mathrm{~T} 2$ & $\mathrm{~T} 3$ \\
\hline & \multicolumn{4}{|c|}{---------------------------\%"--------------------------- } \\
\hline Jagung Kuning & 57,00 & 55,00 & 54,00 & 54,00 \\
\hline Bekatul & 15,00 & 15,00 & 14,00 & 12,00 \\
\hline Tepung Ikan & 4,00 & 4,00 & 4,00 & 4,00 \\
\hline poultry meat meal (PMM) & 4,00 & 4,00 & 4,00 & 4,00 \\
\hline Bungkil Kedelai & 15,00 & 15,00 & 15,00 & 15,00 \\
\hline meat bone meal (MBM) & 4,00 & 4,00 & 4,00 & 4,00 \\
\hline Tepung Wortel & 0,00 & 2,00 & 4,00 & 6,00 \\
\hline Premix & 1,00 & 1,00 & 1,00 & 1,00 \\
\hline Jumlah & 100,00 & 100,00 & 100,00 & 100,00 \\
\hline \multicolumn{5}{|l|}{ Kandungan Nutrisi : } \\
\hline Protein Kasar (\%) & 19,57 & 19,61 & 19,60 & 19,56 \\
\hline Energi Metabolis (kkal/kg) & $3.062,91$ & $3.047,03$ & $3.038,50$ & $3.037,30$ \\
\hline Serat Kasar $(\%)$ & 10,45 & 10,67 & 10,72 & 10,57 \\
\hline Lemak Kasar (\%) & 3,57 & 3,55 & 3,47 & 3,35 \\
\hline \multirow[t]{2}{*}{$\mathrm{Ca}(\%)$} & 1,44 & & 1,45 & 1,45 \\
\hline & \multicolumn{2}{|c|}{1,44} & & \\
\hline \multirow[t]{2}{*}{$\mathrm{P}(\%)$} & 0,62 & & 0,63 & 0,60 \\
\hline & \multicolumn{2}{|c|}{0,63} & & \\
\hline Beta karoten $(\%)$ & 0,01 & 0,17 & 0,33 & 0,50 \\
\hline Vitamin A $(\%)$ & 0,14 & 0,23 & 0,33 & 0,43 \\
\hline Vitamin E (\%) & 0,08 & 0,09 & 0,11 & 0,12 \\
\hline
\end{tabular}

Pengukuran massa kalsium dan protein daging dilakukan dengan menggunakan 24 ayam broiler untuk diambil sampel dagingnya. Sampel daging diambil dengan cara menimbang bobot daging karkas, setelah itu mengambil sampel daging bagian dada dan paha yang kemudian dihomogenkan. Sampel daging yang telah halus diambil sebanyak $10 \mathrm{~g}$ untuk dianalisis kadar kalsium dengan metode Atomic Absorption Spectrometry (AAS) dan protein daging dengan metode Kjeldhal. Perhitungan massa kalsium dan massa protein daging dihitung dengan rumus menurut Suthama (2003) :

$$
\begin{gathered}
\text { Massa protein daging } \\
=\text { Kadar protein }(\%) \text { x Bobot daging karkas }(\mathrm{g}) \\
\text { Massa kalsium daging } \\
=\text { Kadar Ca daging }(\%) \text { x bobot karkas }(\mathrm{g})
\end{gathered}
$$

\section{HASIL DAN PEMBAHASAN}

\section{Massa Kalsium Daging}

Penggunaan tepung limbah wortel pada ransum terhadap massa kalsium daging ayam yang tertera pada tabel 4 tidak menunjukkan pengaruh yang signifikan
$(\mathrm{P}>0,05)$. Hal ini menunjukkan bahwa penggunaan tepung limbah wortel hingga $6 \%$ belum bisa mempengaruhi jumlah kandungan kalsium dalam pakan (Tabel 2 dan 3). Menurut Olalude et al, (2015) menyatakan bahwa wortel mengandung beberapa mineral penting berupa kalsium hingga $55 \mathrm{mg}$, fosfor $43 \mathrm{mg}$ dan besi 1,67 mg. Artinya penggunaan tepung limbah wortel hingga $6 \%$ hanya menyumbang 33-55 mg kalsium, seperti terlihat pada tabel 2 dan 3. Hal ini menyebabkan konsumsi kalsium sama karena konsumsi ransum yang sama, dimana konsumsi kalsium berkaitan dengan kadar kalsium dalam ransum dan konsumsi ransum. Menurut Suprapto et al. (2012) menyatakan bahwa asupan mineral berupa $\mathrm{Ca}$ dan $\mathrm{P}$ dipengaruhi oleh konsumsi ransum. Konsumsi ransum dan konsumsi kalsium yang sama menyebabkan asupan kalsium yang dideposisi ke dalam daging akan menjadi sama, sehingga mengakibatkan kadar kalsium dalam daging menjadi sama dan berakibat pada massa kalsium daging menjadi sama. Menurut Levkut et al. (2010) menyatakan bahwa massa kalsium daging yang tidak berbeda dapat disebabkan oleh 
asupan kalsium pakan yang sama dan keberadaan kalsium dalam pakan.

Konsumsi protein yang sama juga mempengaruhi massa kalsium yang sama. Hal ini karena protein yang masuk dari konsumsi protein dalam jumlah yang sama sehingga protein yang mengikat kalsium dengan mekanisme Calcium Binding Protein (CaBP) akan sama dan absorbsi kalsium untuk dideposisi dalam daging akan berjumlah sama pula. Menurut Syafitri et al. (2015) bahwa massa kalsium daging berhubungan dengan kecernaan protein karena ketersediaan kalsium sangat berhubungan dengan asupan protein dengan membentuk ikatan Calcium Binding Protein (CaBP) yang akan membawa kalsium dalam sel mukosa usus dan diangkut oleh pembuluh darah menuju jaringan yang dibutuhkan.

Wortel mengandung $\beta$-karoten atau provitamin A yang akan efektif hanya 1/6 nya, sehingga penggunaan wortel $6 \%$ setara dengan $1 \%$ vitamin $\mathrm{A}$ dan belum dapat menyebabkan perubahan massa kalsium daging. Menurut Kane (2009) menyatakan bahwa $\beta$-karoten yang diserap sebagai vitamin A sebesar $60-75 \%$ sedangkan $15 \%$ akan diserap oleh tubuh dalam bentuk utuh, sedangkan konversi $\beta$-karoten menjadi vitamin A yaitu $6: 1$ atau setiap 1,8 ug $\beta$ karoten memberikan 0,3 ug vitamin A. Kandungan $\beta$-karoten dalam wortel kurang efektif dalam mempengaruhi penyerapan kalsium dalam pakan sehingga massa kalsium daging menjadi sama.

\section{Massa Protein Daging}

Penggunaan tepung limbah wortel pada ransum terhadap massa Protein daging ayam yang tertera pada tabel 4 menunjukkan pengaruh yang signifikan $(\mathrm{P}<0,05)$ menurun pada taraf 4\% (T2) dan 6\% (T3). Hal ini diduga kalsium dalam tepung limbah wortel dalam bentuk kandungan kalsium berupa ion bebas. Kalsium dalam bentuk ion bebas akan mengaktifan enzim protease, yang dapat mendegradasi protein. Konsumsi kalsium dan massa kalsium sama namun sudah dapat mengatifkan enzim calcium activated neutral protease (CANP) untuk mendegradasi protein, yang berakibat massa protein menjadi turun. Menurut Winedar et al, (2006) menyatakan bahwa massa protein daging ayam berhubungan dengan massa kalsium daging karena jumlah nilai massa protein daging dipengaruhi oleh kadar kalsium yang berbentuk ion. Ditambah dengan menurut Bikrisima et al. (2014) menyatakan bahwa kalsium khususnya dalam bentuk ion yang terdapat pada daging dapat dilihat dari besarnya massa kalsium pada daging, kalsium dalam bentuk ion berperan mempengaruhi deposisi protein daging, dikarenakan sebagai activator enzim proteolitik otot calcium activated neutral protease (CANP) yang berfungsi untuk degradasi protein daging.

Tabel 4. Rataan massa protein daging, dan massa kalsium daging.

\begin{tabular}{|c|c|c|c|c|}
\hline \multirow{2}{*}{ Parameter } & \multicolumn{4}{|c|}{ Perlakuan } \\
\hline & T0 & T1 & $\mathrm{T} 2$ & T3 \\
\hline $\begin{array}{l}\text { Massa } \\
\text { Kalsium } \\
\text { Daging (mg) }\end{array}$ & 17,73 & 18,44 & 13,07 & 16,67 \\
\hline $\begin{array}{l}\text { Massa Protein } \\
\text { Daging }(\mathrm{g})\end{array}$ & $186,43^{\mathrm{a}}$ & $171,79^{\mathrm{ab}}$ & $146,48^{\mathrm{bc}}$ & $152,42^{\mathrm{bc}}$ \\
\hline
\end{tabular}

Kecernaan protein yang sama akibat penggunaan tepung limbah wortel hingga $6 \%$ juga dapat mempengaruhi penurunan massa protein. Hal itu dikarenakan kecernaan yang sama menandakan bahwa asupan protein yang diserap dan dicerna oleh ayam dalam jumlah yang sama. Asupan protein untuk sintesis protein tersebut tidak dapat mengimbangi aktifitas enzim CANP yang lebih aktif pada perlakuan penggunaan tepung limbah wortel dengan taraf 4\% (T2) dan 6\% (T3) dalam mendegradasi protein, sehingga mengakibatkan terjadi penurunan pada massa protein daging. Menurut Minawarti et al, (2013) bahwa massa protein daging merupakan suatu indikator untuk melihat baik atau buruknya deposisi protein, sehingga Asupan protein berperan penting dalam deposisi protein melalui sintesis dan degradasi protein. Menurut Fanani et al, 
(2016) menyatakan Tingginya aktivitas enzim calcium activated neutral protease (CANP) dalam daging yang berfungsi untuk mendegradasi protein daging dapat mempengaruhi laju degradasi protein yang berakibat pada deposisi protein pada daging atau massa protein daging.

\section{KESIMPULAN}

Perlakuan penggunaan tepung limbah wortel pada ransum hingga $6 \%$ memberikan pengaruh yang sama terhadap massa kalsium daging, tetapi menurunkan massa protein berakibat menurunnya. Penggunaan tepung limbah wortel dalam ransum tidak boleh melebihi taraf 2\%. Penggunaan tepung wortel sebaiknya tidak melebihi $2 \%$, hal ini karena dapat menyebabkan massa protein daging menjadi menurun yang berakibat pada menurunnya pertumbuhan pada ayam.

\section{DAFTAR PUSTAKA}

Brikisima, S.H.L., L.D. Mahfudz dan N. Suthama. 2014. Kemampuan produksi ayam broiler yang diberi tepung jambu biji merah sebagai sumber antioksidan alami. J.Ilmu dan Teknologi Peternakan. 3(2) : 69-75.

Diva, J.C.S. 2014. Nutritional and health benefits of carrots and their seed extracts. J. Food and Nutrition Sciences. 5 : 2147-2156.

Fanani, F.A., N. Suthama, dan B. Sukamto. 2016. Efek penambahan umbi bunga dahlia sebagai sumber Inulin terhadap kecernaan protein dan produktivitas ayam lokal persilangan. J. Kesehatan Hewan. 10 (1) : 58-62

Levkut, M., A. Marcin, L. Lenhardt, P. Porvaz, V. Revajova, B. Soltysova, J. Blanar, Z. Sevcikova, dan J. Pistl. 2010. Effect of sage extract on alkaline phosphatase, enterocyte proliferative activity and growth performance in chikens. Acta Veterinaria Brunensis J. 79 : 177-183.
Mirnawati, B. Sukamto, dan V.D. Yunianto. 2013. Kecernaan protein, retensi nitrogen, dan massa protein daging ayam broiler yang diberi ransum daun murbei (Morus alba L.) yang difermentasi dengan cairan rumen. J. Ilmu dan Teknologi Peternakan. 3(1) : 25-32.

Olalude, C.B., F. O. Oyedeji, and A.M. Adegboyega. 2015.2 Physicochemical analysis of daucus carota (carrot) juice for possible industrial applications. Journal of Applied Chemistry. 8(8):110-113.

Suprapto, W., S. Kismiyati, dan E. Suprijatna. 2012. Pengaruh penggunaan tepung kerabang telur ayam ras dalam ransum burung puyuh terhadap tulang tibia dan tarsus. Anim. Agri. J. 1(1): 75-90.

Steel, R.G.D., dan J.W. Torrie.1993. Prinsip dan Prosedur Statistika: Suatu Pendekatan Biometrik. Terjemahan: B. Sumantri. PT Gramedia Pustaka Utama, Jakarta.

Suthama, N. 1990. Mechanism of Growth Promotion Induced by Dietary Thyroxine in Broiler Chicken. Kagoshima University, Kagoshima. (Disertasi)

Suthama, N. 1991. Interaksi hormon tiroksin dan testosteron terhadap metabolisme protein pada ayam broiler yang diberi pakan berprotein tinggi. Prosiding Seminar Nasional Usaha Peningkatan Produktivitas Peternakan dan Perikanan. Universitas Diponegoro. Semarang : 348-353.

Suthama, N. 2003. Metabolisme protein pada ayam kampong periode pertumbuhan yang diberi ransum memakai dedak padi fermentasi. J. Pengemb. Pet. Trop. Edisi Spesial : 44-48.

Syafitri, Y.E., V.D. Yunianto dan N. Suthama. 2015. Pemberian ekstrak 
daun beluntas (Pluchea indica Less) dan klorin terhadap massa kalsium dan massa protein daging ayam broiler. Anim. Agri. J. 4(1) : 155-164.

Tanuwiria, U. H., A. Rohana, Mansyur, dan L. B. Nuryanti. 2008. Pemanfaatan limbah wortel dalam ransum dan pengaruhnya terhadap metabolisme rumen dan performen produksi sapi perah. Seminar Nasional Pengembangan Agroindustri Usaha Persusuan untuk Perbaikan Gizi masyarakat dan kesejahteraan peternak, Universitas Gadjah Mada. Yogyakarta : 107-113

Winedar, Hanifiasti, S. Listyawati dan Sutarno. 2006. Daya cerna protein pakan, kandungan protein daging dan pertambahan berat badan ayam broiler setelah pemberian pakan yang difermentasi dengan effective microorganisms-4 (EM-4). J. Bioteknol. 3 (1):14-19. 